\title{
Role of curcumin in regulating $p 53$ in breast cancer: an overview of the mechanism of action
}

This article was published in the following Dove Press journal:

Breast Cancer - Targets and Therapy

\author{
Wamidh H Talib' \\ Sonia A Al-hadid' \\ Mai B Wild Ali' \\ Intisar Hadi AL-Yasari ${ }^{2}$ \\ Mohammed R Abd Ali ${ }^{3}$ \\ 'Department of Clinical Pharmacy \\ and Therapeutics, Applied Science \\ Private University, Amman, Jordan; \\ ${ }^{2}$ Food Technology Department, Faculty \\ of Food Science, AL-Qasim Green \\ University, Babylon, Iraq; ${ }^{3}$ Faculty \\ of Nursing, University of Babylon, \\ Babylon, Iraq
}

\begin{abstract}
: p53 is a tumor suppressor gene involved in various cellular mechanisms including DNA repair, apoptosis, and cell cycle arrest. More than 50\% of human cancers have a mutated nonfunctional p53. Breast cancer (BC) is one of the main causes of cancer-related deaths among females. p53 mutations in $\mathrm{BC}$ are associated with low survival rates and more resistance to the conventional therapies. Thus, targeting p53 activity was suggested as an important strategy in cancer therapy. During the past decades, cancer research was focused on the development of monotargeted anticancer therapies. However, the development of drug resistance by modulation of genes, proteins, and pathways was the main hindrance to the success of such therapies. Curcumin is a natural product, extracted from the roots of Curcuma longa, and possesses various biological effects including anticancer activity. Previous studies proved the ability of curcumin to modulate several signaling pathways and biomolecules in cancer. Safety and cost-effectiveness are additional inevitable advantages of curcumin. This review summarizes the effects of curcumin as a regulator of $\mathrm{p} 53$ in $\mathrm{BC}$ and the key molecular mechanisms of this regulation.
\end{abstract}

Keywords: natural products, apoptosis, p53, breast cancer, Curcuma longa

\section{Introduction}

Cancer is one of the most common causes of death globally. In the late 20th century, researchers predicted about 1.3 million new invasive cancer cases in USA and 560,000 deaths which means 1,500 Americans died from cancer per day. ${ }^{1}$ Unfortunately, this number increased and reached around 1.6 million new cases and 589,430 deaths in 2015 with almost 1,600 deaths per day. ${ }^{2}$ By 2030, WHO International expected that $25 \%$ of people around the world will have at least one cancer type. More than $60 \%$ of new cases are expected in low- and middle-income regions. ${ }^{3}$

An interesting study showed that approximately 14.1 million people in USA had a history of cancer in all sites. ${ }^{4}$ A preliminary study estimated that 3,131,440 women live in USA diagnosed with invasive breast cancer (BC). In 2014 alone, 232,670 women had invasive $\mathrm{BC}$ and almost $72 \%$ of them were older than 60 years. ${ }^{4}$ Recent statistics showed a marked increase in new BC cases, and there were 231,840 cases in 2015 while clinicians estimated 246,660 new cases in the followed year. ${ }^{2,5}$ In 2017, new BC in situ cases were the highest among females at the age of 50-59 years. ${ }^{6}$

The use of natural products in cancer therapy is an active area of research, and previous studies reported the successful use of some plant extracts and pure compounds to treat different cancers. ${ }^{7,8}$ Curcumin is one of the extensively studied natural products. It has numerous health benefits and many pharmacological effects including
Correspondence: Wamidh H Talib Department of Clinical Pharmacy and Therapeutics, Applied Science Private University, Al-Arab Street, Shafa Badran, Amman, 11931-166, Jordan Tel +962 6560999 ext I |4I Email w_talib@asu.edu.jo 
antiproliferation, apoptosis induction, antiangiogenesis, antiinflammatory, and antioxidant activities. Its low cost and ability to attack multiple targets in cancer make it a suitable agent to be explored for cancer management. ${ }^{9}$

p53 is a tumor suppressor gene involved in many metabolic processes including apoptosis induction, repairing DNA damage, and inducing arrest in cell cycle. More than $50 \%$ of human tumors lost the protective effect of $\mathrm{p} 53$ which results in resistance to apoptosis and sustained proliferation. ${ }^{10}$ Selective inhibition of cancer cells requires specific disruption of growth mechanisms used by these cells with limited damage to normal cells. In this context, p53 is considered as one of the suitable targets as more than half of the human cancers have mutated p53. ${ }^{11}$

In this review, the effects of curcumin in apoptosis induction and p53 activity regulation are discussed.

\section{Side effects of conventional anticancer therapies}

Chemotherapy has been and remains one of the first available options for BC patients with early or late stages. ${ }^{12}$ Unfortunately, chemotherapeutics cause a number of serious, unpleasant, may be fatal, side effects. In addition, these drugs fail to evade multidrug resistance phenomenon which limited their efficacy. ${ }^{13}$ Many years ago, cardiac toxicity was a wellknown side effect of both anthracyclines and mitoxantrone which cause arrhythmias and congestive heart failure (CHF) with cumulative doses of more than $160 \mathrm{mg} / \mathrm{mL}$ due to oxidative stress, while antimetabolites such as fluorouracil cause CHF due to vasospasm. ${ }^{14}$

Cancer patients who undergo chemotherapy treatment in concomitant with other antiemetic drugs and opioids will develop severe painful constipation and remarked downstream effect on colonic motility and gastrointestinal (GI) transit. ${ }^{15}$ Furthermore, the platinum-based chemotherapeutic agent, oxaliplatin, induces apoptosis in crypts within the colon and causes excessive secretions, and thus some patients develop diarrhea. ${ }^{16,17}$ Cisplatin, an alkylating antitumor agent, causes heart block and ischemia, ${ }^{14}$ as well as it causes severe nephrotoxicity due to the enormous renal proximal tubular cell death which will increase serum creatinine levels after a few days of administration. ${ }^{18}$ Additional side effects noticed by researchers were ototoxicity, hepatotoxicity, and declining of white and red blood cells among cisplatin users. ${ }^{19}$ At the very least, the short-term use of chemotherapy causes ephemeral immunosuppression and thus induces serious parasitic, viral, and fungal infections..$^{20}$
Radiotherapy (RT) is another standard anticancer therapy. ${ }^{21}$ However, its use is associated with many side effects. ${ }^{22}$ Patients who are sensitive to radiation were expected to develop subcutaneous and lung fibrosis. ${ }^{23}$ In addition, the local treatment of a squamous cell carcinoma of head and neck by RT will certainly develop skin toxicities such as erythema and desquamation. ${ }^{24}$ Furthermore, BC women who received RT experienced emotional discomfort and pain. One patient did not repeat the therapy after feeling an extensive burning in the breast. ${ }^{25}$

Moreover, late symptoms may emerge due to the use of RT, such as proctitis, diarrhea, and cystitis during 2 years of follow-up using a radical RT in prostate cancer patients. ${ }^{26,27} \mathrm{~A}$ case study reported another late symptom which is the second malignancy; four out of 14,000 patients who had been treated for their childhood Wilms tumor using a radiation therapy developed hepatocellular carcinoma as a second malignant neoplasm (SMN) and death occurs on average of 3 months after diagnosis. ${ }^{28,29}$ These side effects encouraged scientists to search for alternative therapeutic options that exhibit low toxicity and high ability to selectively target cancer cells. Plant-derived natural products are an ideal source of such therapies due to their diversity and capacity to target multiple growth pathways in cancer.

\section{Curcumin in cancer research}

For years now, the world has been turning to use herbal remedies and natural products to extract effective biological constituents against cancer. This trend is due to serious side effects of the conventional treatments. , $^{70,31}$

WHO reported that $80 \%$ of world inhabitants depend on plant-derived traditional medicine in health care. ${ }^{32}$ In 2050 , the global market of pharmaceutical preparations derived from plants will grow and reach $\$ 5.0$ trillion. ${ }^{33}$ The most important herbal trademarket (China) exports 120,000 tones of herbal drugs per year. ${ }^{34}$ There are more than 250,000 plant species in our globe, and only $10 \%$ were tested for certain biological evidence. ${ }^{35,36}$ However, half of the currently marketed drugs are of plant origin. ${ }^{37}$

Many plant-derived natural products have anticancer potential. ${ }^{38}$ From 1981 to 2010, 30 years of effort showed that around $80 \%$ of the anticancer drugs isolated directly from natural products or mimicked them, while only $20 \%$ were synthesized in the laboratories. ${ }^{39}$

One of the most struggling issues in cancer therapy is multidrug resistance phenomenon which arises in $30-80 \%$ of patients who undergo chemotherapy. ${ }^{40}$ Fortunately, most of 
the natural products have been able to resist this phenomenon such as curcumin while most of the synthetic agents failed to deal with it. ${ }^{40}$

As reported by Shishodia et al, curcumin was isolated by Vogel in 1842 and the chemical structure was identified by Lamp in $1910 .^{41}$ It was derived from the roots of Curcuma longa and has multiple health benefits including antioxidant, anti-inflammatory, chemopreventive, and chemotherapeutic effect. $^{42}$

C. longa or turmeric is cultivated widely in India and contains $60-70 \%$ of curcumin ([1E,6E]-1,7-bis[4-hydroxy3-methoxyphenyl]-1,6-heptadiene-3,5-dione; Figure 1). ${ }^{41,43}$ Researchers found that curcumin has many biological activities due to the huge chemical diversity of its metabolites. ${ }^{44}$ The most important metabolites are vanillin and ferulic acid, which have cytotoxic effects represented by overhaul mutated DNA and remove free radicals, respectively. ${ }^{45}$

Curcumin is an ancient herb and has modulated numerous molecular targets in cancer research. It downregulated receptors (Her-2, IR, ER-a, and Fas receptor), growth factors (PDGF, TGF, FGF, and EGF), kinases (JAK, PAK, and mitogen-activated protein kinase [MAPK]), enzymes (ATPase, COX-2, and matrix metalloproteinase enzyme [MMP]), inflammatory cytokines (IL-1, IL-2, IL-5, IL-6, IL-8, IL-12, and IL-18), and transcriptional factors (nuclear factor kappa B protein [NF-кB], Notch-1, and STAT-1, STAT-3, STAT-4, and STAT-5), while it upregulated other targets including p53, death receptor (DR-5), JN-kinase, Nrf-2, and peroxisome proliferator-activated receptor $\gamma\left(\right.$ PPAR $\gamma$ ) factors. ${ }^{46}$

Studies demonstrated that curcumin inhibits both cyclooxygenase-2 enzyme (COX-2) and NF- $\kappa$ B. Therefore, it decreases binding of NF- $\mathrm{B}$ to DNA and overpasses chemoresistance phenomenon in cancer cells. ${ }^{44-47}$

Furthermore, curcumin targets many cancer hallmarks. First, it has an antimetastatic effect through decreasing the expression of MMP-2 and increasing the expression of tissue inhibitor of metalloproteinase-1 (TIMP-1), where both enzymes regulate cell invasion. ${ }^{48}$ Second, it has an antiangiogenic effect by inhibiting the transcription of vascular endothelial growth factor (VEGF) and basic fibroblast growth factor (bFGF). ${ }^{49}$ In addition, curcumin has a potential to bind

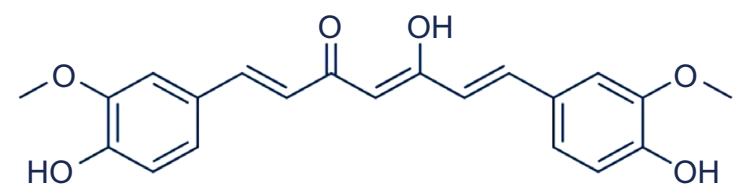

Figure I Chemical structure of curcumin. to aminopeptidase $\mathrm{N}$ (CD13) and thus inhibits VEGF receptor, decreases the expression of MMP-9, and withstands tyrosine kinase signaling pathway. ${ }^{49}$ Also, it decreases the expression of cyclin-dependent protein kinase-2 (CDK-2) in colon cancer. ${ }^{50}$

An interesting study on prostate cancer cell lines, PC3 and DU145, inferred that curcumin has a dose-dependent effect on both cell viability and proliferation. Researchers concluded that curcumin depresses the survival of previously mentioned cell lines at a concentration of $50 \mu \mathrm{M}$. A time-dependent inhibition of curcumin on the same cell lines decreased survival by $50 \%$ in 48 hours. $^{51}$

Recently, cancer stem cells showed an essential role in progressing many types of cancers. Curcumin can defeat cancer through targeting these cells such as Burkitt lymphoma, acute myeloid leukemia, liver, and colorectal cancer. ${ }^{52,53}$ In specific, the activity of BC stem cells (BCSCs) was inhibited by curcumin after Western blot analysis of BCSC markers (CD44, ALDH1A1, Nanog, and Oct4) that were substantially downregulated by curcumin also in MCF-7 cells. On the other hand, curcumin induced apoptosis of BCSCs by reducing BCL-2 protein levels and increasing many apoptotic proteins such as Bcl-2-associated X protein (Bax), caspase-3, caspase-8, and caspase- $9 .{ }^{54}$

Mainly, there are factors affecting curcumin efficacy such as low hydrophilicity, low bioavailability, and rapid metabolism; thus, it delivered in several formulations that enhanced the solubility, efficacy, and cytotoxicity of this phytochemical. ${ }^{55}$ Curcumin has been used in about 26 clinical trials of several diseases starting from psychotic disorders, Alzheimer disease, cognitive ailment, and ending with many types of cancer. ${ }^{56}$ As a lipophilic compound, it showed frustrating clinical studies when given orally; thus, it formulated in various drug delivery systems such as nanoparticle, liposome, microemulsion, and implantable devices. Nanoparticle-formulated curcumin gained several advantages, increased oral bioavailability by 26 -fold, and lengthened half-life and retention time in gastric acids which enhanced its efficacy. ${ }^{57} \mathrm{An}$ interesting study on MCF-7 cells compared between the anticancer effects of free curcumin and curcumin loaded on a nanocarrier used increasing concentrations of both delivery formulas $(0.5-70 \mu \mathrm{M})$ and resulted in boosting the cytotoxicity of curcumin and time of the release and reducing $\mathrm{IC}_{50}{ }^{58}$

\section{Role of $\mathrm{p} 53$ in cancer progression}

Human p53 gene can encode 12 different isoforms that normally formed through an alternative initiation of translation and alternative splicing. ${ }^{10}$ The p53 protein composed of 393 
amino acids which grouped into six domains. First is the N-terminal region which consists of the transcription activation domain (TAD) and is subdivided into two regions (TD1 and TD2). Second is the proline-rich region (PRR), which is constant in a majority of p53s. Third is the central core domain (p53C), where the DNA-binding part is located and more than $90 \%$ of human mutations take place. Fourth is a nuclear localization signal domain. Fifth is a tetramerization (TET) domain. Sixth is the C-terminal domain (CT), which is the nonspecific DNA-binding domain. ${ }^{59}$

p53 is considered a target for many posttranslational modifications, such as phosphorylation, acetylation, and ubiquitination. ${ }^{10}$ Several signals can generate p53 within minutes, including ultraviolet (UV) radiation, hypoxia, blockage of transcription, oncogene signaling, ionizing radiation, and lack of nucleotides. Then, p53 will induce cell cycle arrest, and apoptosis and block angiogenesis and DNA repair (Figure 2). ${ }^{60}$

Any mutation occurs in p53 may lead to an oncogenic action. ${ }^{61}$ Most human cancers have a mutated p53 gene which leads to a total or partial loss of its function. ${ }^{62}$ This mutant p53 is associated with cancer due to loss of function (LoF) and dominant negative (DN) and gain-of-function (GoF) effects. ${ }^{10}$

Only about $5 \%$ of p53 mutations found in the regulatory domains, whereas $95 \%$ found in the central region which is responsible for a sequence-specific DNA binding..$^{63}$ Frequently, mutations take place in this region of p53 (residues 102-292). Unlike other tumor suppressor genes, more than $85 \%$ of p53 mutations caused by a single amino acid substitution. ${ }^{64}$
The central role of p53 in cell survival makes it a target for many therapeutic anticancer strategies. Restoring endogenous p53 expression resulted in tumor regression of animal models, and response varies depending on tumor type. For example, p53 restoration induces apoptosis in lymphoma, while it causes suppression of cell growth and senescence in sarcoma; these successful results support the research for treating cancer by pharmacological reactivation of $\mathrm{p} 53 .^{65}$ In BC, p53 suppression increases a gene expression that encodes Burkitt lymphoma receptor BLR-1 which binds to chemokine ligand 13 (CXCL13) and thus activates both cell migration and metastasis. ${ }^{66}$

p53 protein plays a substantial role in activating adaptive cellular responses to environmental stresses. There are many routes to activate $\mathrm{p} 53$ protein such as posttranslational modification, protein stabilization, and protein-protein interaction. ${ }^{67}$ After all, the main route is the p53-murine double minute 2 (MDM2) pathway which destabilizes p53. ${ }^{68}$

p53 is a short-lived tumor suppressor protein, and its levels are controlled by MDM2 protein. The regulation process involves binding of the MDM2 protein to the transactivation domain of $\mathrm{p} 53$ which is followed by ubiquitination and rapid turnover of $\mathrm{p} 53 .{ }^{67}$

Wild-type p53 increases the expression of MDM2, and the first intron of MDM2 binds to p53 on a DNA-binding region near the promoter which will induce gene expression. When additional levels of MDM2 are produced, p53's activity will decrease, which is a mechanism called autoregulatory feedback loop. ${ }^{69}$

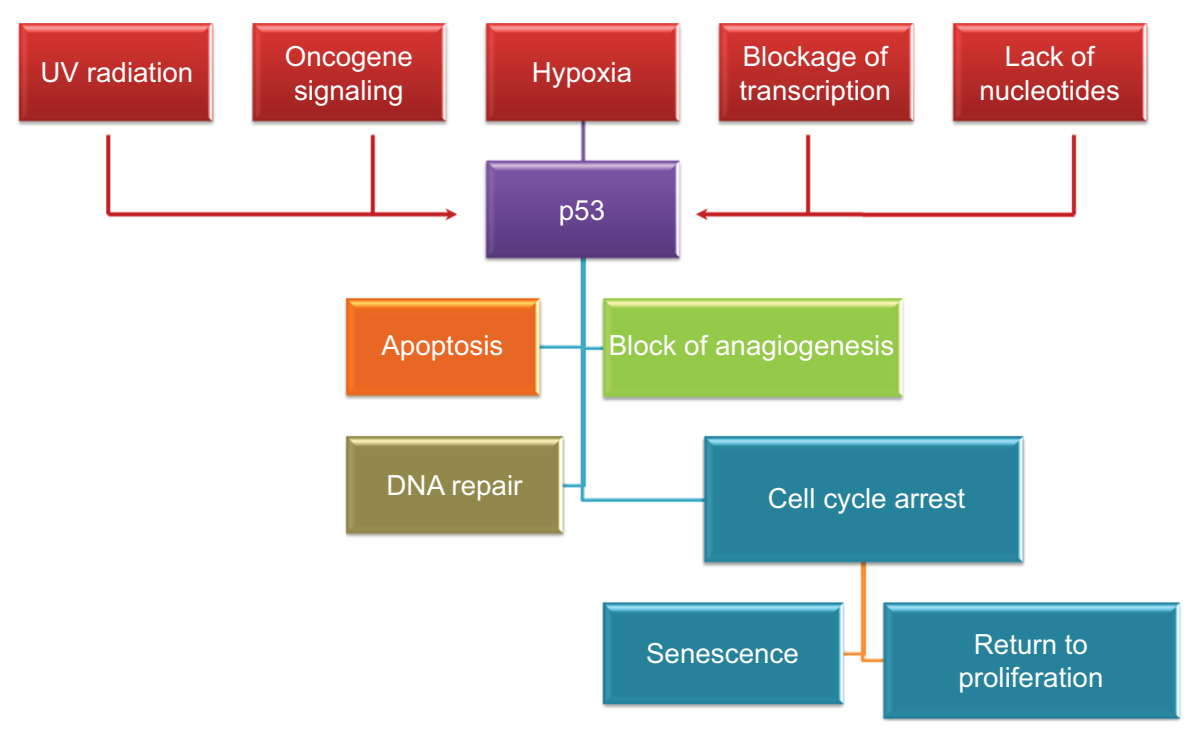

Figure 2 p53 stimulation signals and downstream effects. Abbreviation: UV, ultraviolet. 
Mutated MDM2 can negatively regulate p53 levels by degrading the phosphorylated form of this protein, and it can be amplified in 30-40\% of human sarcomas which indicates the MDM2 critical role in developing this type of cancer. ${ }^{70}$

Any loss in the p53 function will contribute to cancer development due to the major role of this protein in preventing tumor growth at several points of the malignancy process. ${ }^{71,72}$ The function of p53 lost in many different ways; the most common one is a loss of the chromosomal region that contains one allele of the gene and mutations in the other allele. ${ }^{70}$

\section{Role of p53 in apoptosis}

Apoptosis can be induced by p53 through the activation of caspase-cascade pathway in both transcription-dependent or transcription-independent mechanisms. ${ }^{73,74}$ Transcriptionindependent mechanism occurs when p53 induces the transcription of a gene encoding protein such as the Fas protein which is essential to promote apoptosis. ${ }^{73,75}$ On the other hand, the transcription-dependent mechanism occurs when p53 boosts the expression of pro-apoptotic proteins such as Bax which is the key of the intrinsic pathway of apoptosis. ${ }^{74,75}$

Therapeutic strategies of targeting p53 focused on increasing p53 levels to induce apoptosis, inhibiting the interaction between p53 and MDM2 and restoring wild-type p53. ${ }^{76}$ The genetic mutation that activates oncogenes can inhibit many tumor suppressor genes and lead to cancer development. Tumor-associated p53 mutations inhibit the activity of p53 and trigger an alteration in the activity of pro-apoptotic proteins. ${ }^{77,78}$

Deficiency in p53 levels plays a role in cancer drug resistance; a clinical study showed that tumor cells with a mutanttype p53 were resistant to chemotherapy and radiotherapy. ${ }^{79}$ Additional clinical studies are associated with poor clinical outcomes in cancer therapy due to an inhibition of functional p53 family proteins such as p73 and p63. Furthermore, a mutant-type p53 can upregulate the expression of some genes involving multidrug resistance-1 (MDR1) gene, which is the contributor to the drug resistance phenomenon. ${ }^{76}$

A positive correlation was observed between $\mathrm{p} 53$ function and the degree of response to certain cancer therapies. For instance, tumors with mutated p53 such as lung cancer and prostate cancer exhibited poor response to chemotherapy. In addition, p53 mutations positively correlated with doxorubicin resistance in $\mathrm{BC}$ patients. ${ }^{80}$

\section{The role of curcumin in regulating $\mathrm{p} 53$ in BC}

In healthy human adults, 150 billion $\left(10^{9}\right)$ cells out of 37.2 trillion $\left(10^{12}\right)$ cells will undergo apoptosis on daily basis. ${ }^{81}$
Curcumin has an anti-proliferative effect and acts as a proapoptotic agent in many cancer cell lines. ${ }^{82}$ It can induce apoptosis by $\mathrm{p} 53$ activation and regulation of other apoptotic proteins. ${ }^{83}$ Specifically, p53 is activated by curcumin after it is translocated into the nucleus of a cancer cell. ${ }^{84}$ In addition, curcumin upregulates the expression of apoptotic genes such as TRAP3 and MCL-1 and downregulates other genes such as TRAIL and AP13 in BC cells. ${ }^{85}$

The exposure of human BC cell lines (MCF-7) to curcumin induces p53 DNA-binding activity and increases p53 to its maximum level; this is associated with the increased levels of an apoptotic activator known as Bax. ${ }^{86,87}$ Further studies reported additional upregulated genes by curcumin in this cell line which included many genes induced by the tumor suppressor protein (p53) and which are involved in p53-mediated programmed cell death. ${ }^{88,89}$

Drastically, curcumin induces Bax and p21 expression which results in apoptosis and cell cycle arrest, respectively. ${ }^{82}$ p21 is one of the downstream genes that are being transactivated by $\mathrm{p} 53 .{ }^{90}$ In fact, curcumin activates p53 directly which repairs DNA and it also inactivates serine/threonine-specific protein kinase (Akt) which resulted in increased expression of Bax gene and induction of apoptosis..$^{91,92}$

In another human BC cell line (MDA-MB-231), curcumin induces apoptosis in a dose-dependent manner through increasing the levels of both Bax and p21 proteins while reducing an antiapoptotic protein B cell lymphoma-2 (Bcl-2) levels along with decreasing p53 levels. The latter effect does not confirm many other studies which have reported that curcumin induces apoptosis by p53-dependent Bax in human BC cell line (MCF-7). ${ }^{93-95}$

Curcumin regulates many molecular targets which involved in the intrinsic apoptotic pathway of BC cells, and it upregulates the serine phosphorylation of p53 and inhibits the phosphorylation of Akt which modulates the direct action of p53 on the caspase-cascade network, ${ }^{96,97}$ It downregulates mutant p53 and activates caspase-3, the hallmarks of apoptosis, which will prevent cancer progression. ${ }^{98}$

Cancer cells that express high levels of mutant p53 are more sensitive to curcumin treatment than those that express a wild-type p53; curcumin selectively increases the levels of wild-type p53 at a G2/M phase in deregulated cyclin D1-overexpressing cells. ${ }^{99}$ When using high doses of curcumin, not only it exerts an effect on G2/M phase but also it induces $\mathrm{S}$ phase with no observed pre-G1 peak. ${ }^{100}$

In addition, curcumin may induce apoptosis through activating p53 and downregulating PI3K, p-Akt, and p-mTOR substrates; PI3k/Akt/mTOR is a well-known survival pathway 


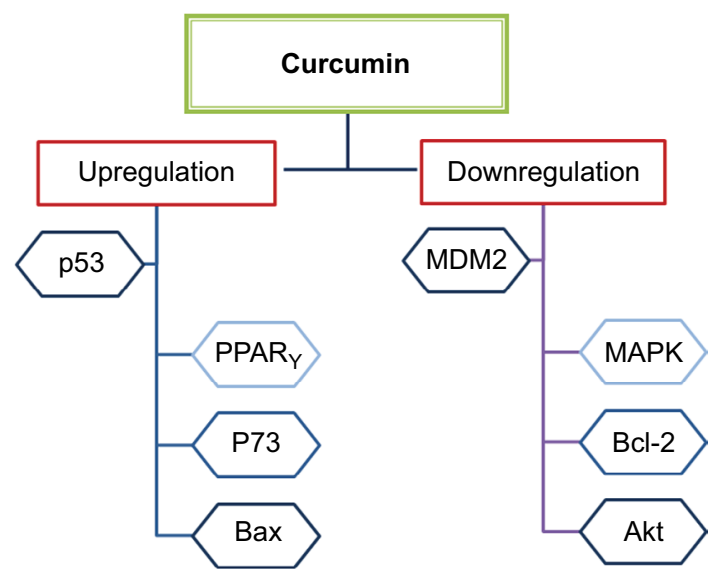

Figure 3 The role of curcumin in regulating $\mathrm{p} 53$ in $\mathrm{BC}$. Abbreviation: BC, breast cancer. activated by cancer cells progressively. ${ }^{87,101}$ In another mechanism, curcumin activates PPAR $\gamma$ which transactivates p53, the major mediator of cell senescence. ${ }^{102}$ Curcumin alone can induce the expression of p53 gene (Trp53) and thus restore the level as well as the function of the p53 protein. ${ }^{103,104}$

In multiple myeloma cancer cells treated with curcumin, the expression of $\mathrm{p} 53$ and Bax genes is upregulated, while the expression of the MDM2 gene is downregulated. ${ }^{105}$ Curcumin causes overexpression and reactivation of $\mathrm{p} 53 .{ }^{106}$ In the same fashion, it is able to restore the active wild-type p53 form in various cancer cell origins and activates p53 cousin, a p73 protein, which induces apoptosis depending on the mitochondria-mediated pathway. ${ }^{107,108}$

Table I The effects of curcumin on p53 in vitro: a sample of studies

\begin{tabular}{|c|c|c|c|c|}
\hline Cell lines & Tumor inoculation & $\begin{array}{l}\text { Curcumin (dose, } \\
\text { route) }\end{array}$ & Response & Reference \\
\hline $\begin{array}{l}\text { MDA-MB-23I, epithelial } \\
\text { cells of mammary gland; } \\
\text { breast, metastatic mammary } \\
\text { adenocarcinoma } \\
\text { BT-483, epithelial cells of } \\
\text { mammary gland; breast, ductal } \\
\text { carcinoma }\end{array}$ & $\begin{array}{l}\text { LL-I5 medium; I-glutamine, } \\
\text { I0\% FBS and Abs } \\
\text { Dulbecco's Modified Eagle } \\
\text { (DME) medium; I-glutamine, } \\
\text { 10\% FBS and Abs }\end{array}$ & $\begin{array}{l}5 \mu g / \mathrm{mL}, \text { for } \\
48 \text { hours } \\
5 \mu g / \mathrm{mL}, \text { for } \\
48 \text { hours }\end{array}$ & $\begin{array}{l}\sqrt{6} 60-70 \% \text { inhibition of proliferation } \\
\sqrt{ } \mathrm{CDK}-4 \text { expression }\end{array}$ & 126 \\
\hline $\begin{array}{l}\text { T-47D, epithelial cells of } \\
\text { mammary gland; breast, DCIS }\end{array}$ & $\begin{array}{l}\text { RPMI-I } 640 \text { media; } \\
\text { l-glutamine, nonessential } \\
\text { amino acids, I0\% FBS, and } \\
\text { Abs }\end{array}$ & $\begin{array}{l}5-80 \mu M \text { CUR, for } \\
24 \text { hours }\end{array}$ & $\begin{array}{l}\Omega 20-80 \mu \mathrm{M} \text { of CUR significantly } \\
\text { decreases p } 53 \text { protein levels }\end{array}$ & 127 \\
\hline $\begin{array}{l}\text { EAC, mammary epithelial } \\
\text { carcinoma cells }\end{array}$ & $\begin{array}{l}\text { DME or RPMI- } 1640 \\
\text { medium }\end{array}$ & $\begin{array}{l}10 \mu M \text { of CUR, for } \\
2 \text { hours }\end{array}$ & 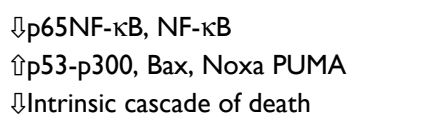 & 128 \\
\hline $\begin{array}{l}\text { MCF-7, epithelial cells of } \\
\text { mammary gland; breast, } \\
\text { adenocarcinoma }\end{array}$ & RPMI-I640 medium & 48 hours & $\begin{array}{l}\text { Uि } 21 \text {, p27 } \\
\text { תCyclin-DI, cyclin-E, cyclin-A, CDK- } \\
2 \text {, and CDK-4 } \\
\text { †Cell cycle arrest }\end{array}$ & 129 \\
\hline $\begin{array}{l}\text { MCF-7, epithelial cells of } \\
\text { mammary gland; breast, } \\
\text { adenocarcinoma }\end{array}$ & DME medium & $\begin{array}{l}10 \mu M \text { of CUR, for } \\
24 \text { hours }\end{array}$ & $\begin{array}{l}\text { 仓Induce apoptosis } \\
\text { ऍpp53 levels, Bax } \\
\text { } \mathrm{Bcl}-\mathrm{xl} / \mathrm{Bax} \text { ratio } \\
\text { nBcl-2 }\end{array}$ & 91 \\
\hline $\begin{array}{l}\text { SK-BR-3 cells, malignant } \\
\text { adenocarcinoma of the breast }\end{array}$ & McCoy's 5A medium & $\begin{array}{l}30 \mu M \text { of CUR, for } \\
24 \text { hours }\end{array}$ & iPhospho-p53, PPAR $\gamma$ & 130 \\
\hline $\begin{array}{l}\text { MCF-7, epithelial cells of } \\
\text { mammary gland; breast, } \\
\text { adenocarcinoma } \\
\text { MDA-MB-23I, metastatic } \\
\text { mammary adenocarcinoma }\end{array}$ & $\begin{array}{l}\text { DME medium } \\
\text { DME medium }\end{array}$ & $\begin{array}{l}\text { I } \mu \mathrm{M} \text { of CUR, for } \\
4 \text { days }\end{array}$ & $\begin{array}{l}\text { תPTEN, p-AKT, p-MDM2, p53 } \\
\text { 仓Protective effect against bisphenol } \\
\text { A, through modulation of miR-19/ } \\
\text { PTEN/AKT/p53 axis }\end{array}$ & $|3|$ \\
\hline $\begin{array}{l}\text { MCF-7, epithelial cells of } \\
\text { mammary gland; breast, } \\
\text { adenocarcinoma }\end{array}$ & DME medium & $\begin{array}{l}40 \mu M \text { of CUR, for } \\
72 \text { hours }\end{array}$ & $\begin{array}{l}\hat{\imath} \text { The number of cells in the early } \\
\text { stages of apoptosis, total p53 levels, } \\
\text { phospho-Bad (ser II2), total Bad } \\
\text { levels } \\
\text { \Phospho-p53 (ser I5) }\end{array}$ & 132 \\
\hline
\end{tabular}

Note: Abs, antibiotics such as penicillin, streptomycin, and amphotericin B; BT-483, ER-positive BC cell line; MDA-MB-23I, ER-negative BC cell line; SK-BR-3, Her-2-positive, ER-negative, PR-negative; T-47D, human BC cell line, positive for both ER and PR.

Abbreviations: Akt, protein kinase B; BC, breast cancer; Bcl-2, B cell lymphoma-2; CDK, cyclin-dependent kinase; CUR, curcumin; DCIS, ductal carcinoma in situ; EAC cells, Ehrlich ascites carcinoma, doxorubicin-resistant cells; ER, estrogen receptor; LL-15 medium, Leibovitz's L-15 medium; PR, progesterone receptor; PTEN, phosphatase and tensin. 
Generally speaking, curcumin is effective in treating cancer cells that contain an abnormal p53 and experience resistance to conventional therapies due to an abnormality in p53 expression or function. Researchers found that curcumin can cause apoptosis independently on p 53 status by increasing superoxide anion production and phosphorylation of oxidative stress proteins. ${ }^{109} \mathrm{In}$ addition, it arrests cancer cells in G1/G0 phase and thus inhibits proliferation in a p53-independent pathway. ${ }^{110}$ Moreover, It induces cell cycle arrest at $\mathrm{G} 2$ phase in p53-deficient $\mathrm{BC}$ cells. ${ }^{111}$

Curcumin exerts a cytotoxic effect through inducing necrotic cell death relying on Bax, caspase-dependent activation, and cytochrome $\mathrm{C}$ release from mitochondria. ${ }^{112} \mathrm{It}$ increases cancer cell apoptosis through an overexpression of p53 and modulation of Bax and Bcl-2 molecules in a dosedependent manner. ${ }^{113,114}$ By the same token, it induces cytotoxic effect due to cancer cell stress sensed by p53, cytoplasmic activation of this protein, and nuclear translocation resulted in restoring the transcriptional function of p53 protein. ${ }^{115}$
Curcumin induces p53 phosphorylation on serine 15 moiety which increases accumulation of this protein in cancer cells. ${ }^{116}$ This phytochemical also induces ROS production which leads to an increase in the levels of p53 and in its downstream proteins such as $\mathrm{p} 21$ and Bax. ${ }^{117}$

Curcumin can induce apoptosis in a p53independent manner, especially in cancer cells that lack a functional p53 protein by downregulating pro-survival protein (Bcl-2) and p38 MAPK. ${ }^{118,119}$ This dietary natural compound inhibits the p300-mediated acylation of p53 that interacts with the p300/CBP complex to enhance its transcriptional effect. ${ }^{120}$ Additionally, other molecular targets for curcumin were reported in several studies testing its anticancer effect against breast cancer. ${ }^{121-125}$ Figure 3 summarizes the main regulatory points of curcumin in BC. In addition, in vitro studies on various $\mathrm{BC}$ cell lines in addition to a brief summary about the inhibitory effects of curcumin in animal models are listed in Tables 1 and 2 , respectively.

Table 2 The effect of curcumin on animal models bearing malignant breast tumors in vivo: a sample of studies

\begin{tabular}{|c|c|c|c|c|}
\hline Animal models & Tumor inoculation & Curcumin (dose, route) & Response & Reference \\
\hline $\begin{array}{l}\text { Female Foxn I }{ }^{\text {nu/nu }} \text { mice, } \\
6-8 \text { weeks old }\end{array}$ & $\begin{array}{l}\text { s.c. injection of mba. } \\
\text { mb23 I cells into the right } \\
\text { side flank, } 2.5 \times 10^{6}\end{array}$ & $\begin{array}{l}\text { Diet containing curcumin } \\
\text { at } 0.6 \%\end{array}$ & $\begin{array}{l}\text { \Proliferation of mba.mb23I cells } \\
\uparrow \text { Apoptosis and } p 53 \text { expression } \\
\sqrt{ } \text { Expression of CD-I, PECAM-I and p } 65\end{array}$ & 133 \\
\hline $\begin{array}{l}\text { Swiss albino mice, } \\
23-25 \mathrm{~g}\end{array}$ & $\begin{array}{l}\text { i.p. injection of EAC cells, } \\
I \times 10^{6}\end{array}$ & CUR $50 \mathrm{mg} / \mathrm{kg}$ body weight & 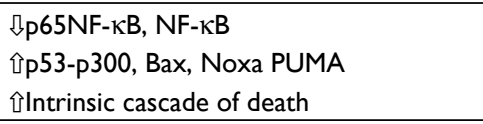 & 128 \\
\hline $\begin{array}{l}\text { Female nu/nu athymic } \\
\text { mice, } 7 \text { weeks }\end{array}$ & $\begin{array}{l}\text { i.p. of } 1.7 \mathrm{mg} \text { of } \\
17 \beta \text {-estradiol before } \\
\text { inoculation, MCF-7 cells } \\
1 \times 107 / \mathrm{mL}\end{array}$ & $\begin{array}{l}100 \mathrm{mg} / \mathrm{kg} \text { of CUR, for } 28 \\
\text { days }\end{array}$ & $\begin{array}{l}\text { Uिp2I, p27 } \\
\text { \Cyclin-DI, cyclin-E, cyclin-A, CDK-2, } \\
\text { and CDK-4 } \\
\text { 仓Cell cycle arrest }\end{array}$ & 129 \\
\hline $\begin{array}{l}\text { Female athymic nude } \\
\text { mice, orthotopic model }\end{array}$ & $\begin{array}{l}\text { Injection of } 2 \times 10^{6} \text { of } \\
\text { MDA-MB-435LVB cells }\end{array}$ & $\begin{array}{l}\text { Fed with powdered } \\
\text { diet containing } 2 \% \mathrm{w} / \mathrm{w} \\
\text { curcumin }\end{array}$ & \NF-kB, COX-2, and MMP-9 & 134 \\
\hline $\begin{array}{l}\text { Female BALB/c nude } \\
\text { mice, } 35-40 \text { days old, } \\
20-22 \mathrm{~g} \text {, xenograft tumor }\end{array}$ & $\begin{array}{l}\text { s.c. with } 2 \times 10^{6} \\
\text { MDA-MB- } 231 \text { cells into } \\
\text { the dorsa of each mouse }\end{array}$ & $\begin{array}{l}\text { i.p., } 50 \mu \mathrm{g} / \mathrm{kg} \text { and } 200 \mu \mathrm{g} / \mathrm{kg} \\
\text { every other day for } 28 \text { days }\end{array}$ & $\begin{array}{l}\widehat{\imath} \mathrm{Apoptosis} \text { in a dose-dependent manner, } \\
\text { Bax protein levels } \\
\checkmark \mathrm{Bcl}-2 \text { protein levels }\end{array}$ & 135 \\
\hline $\begin{array}{l}\text { Female BALB/c mice } \\
\text { weighing about } 18-23 \mathrm{~g}\end{array}$ & $\begin{array}{l}\text { i.p. of EAT cells, } 1 \times 10^{5} / \\
\text { animal }\end{array}$ & $\begin{array}{l}\text { i.p. injection, } 9.9 \mu \mathrm{gg} / \mathrm{mL} \\
\text { daily, } 10 \text { days }\end{array}$ & $\begin{array}{l}\text { ¡Apoptosis, apoptotic bodies, } \\
\text { phosphorylated caspase- } 3\end{array}$ & 136 \\
\hline nu/nu mice, xenografts & $\begin{array}{l}\text { s.c. of BT-474, in the } \\
\text { flank }\end{array}$ & $\begin{array}{l}8.7 \mathrm{mM} / \mathrm{kg} \text { of body } \\
\text { weight/day, dietary } \\
\text { supplementation }\end{array}$ & $\begin{array}{l}\text { ПRelease of cytochrome } \mathrm{c} \text { by } \\
\text { mitochondria, chemotherapy-induced } \\
\text { apoptosis, ROS formation, JNK activation }\end{array}$ & 137 \\
\hline $\begin{array}{l}\text { Female BALB/c, 8-week- } \\
\text { old mice }\end{array}$ & $\begin{array}{l}\mathrm{I} 00 \mu \mathrm{L} \text { of } 4 \mathrm{TI} \text { cell } \\
\text { suspension }\end{array}$ & $\begin{array}{l}\text { 2,000 } \mu \mathrm{g} / \mathrm{kg} \text { body weight } \\
\text { of CUR-encapsulated } \\
\text { microspheres, for } 30 \text { days }\end{array}$ & $\begin{array}{l}\text { תDownregulate } \mathrm{p}-\mathrm{AKT} \\
\text { \Apoptosis, upregulate p27, upregulate } \\
\text { cleaved capspase-3 }\end{array}$ & 138 \\
\hline
\end{tabular}

Note: MDA.MB23I, ER-negative BC cell line; MDA-MB-435LVB cells, human BC cells; Noxa, promotes activation of caspases and apoptosis; 4TI, triple-negative BC cells; nu/nu, nude mice.

Abbreviations: BC, breast cancer; Bcl-2, B cell lymphoma-2; COX-2, cyclooxygenase; CUR, curcumin; EAT, Ehrlich ascitic tumor cells; murine mammary adenocarcinoma; i.p., intraperitoneal; JNK, c-Jun NH2-terminal kinase; MMP-9, matrix metalloproteinases 9; NF-kB, nuclear factor kappa B protein; PECAM-I, platelet and endothelial cell adhesion molecule-I; PUMA, p53 upregulated modulator of apoptosis; s.c., subcutaneously; EAC cells, Ehrlich ascites carcinoma, doxorubicinresistant cells. 


\section{Conclusion}

The numerous health benefits of curcumin, its cost-effectiveness, and its ability to target multiple components in BC make it an ideal agent for further development to produce more effective therapies against BC. This compound interferes with $\mathrm{BC}$ proliferation by upregulating pro-apoptotic proteins (such as p53 and Bax) and downregulating antiapoptotic proteins (such as MDM2 and Bcl-2). Many animal and clinical studies supported the use of curcumin to treat different cancer types including BC. Curcumin can be considered for further testing to augment conventional anticancer therapies. However, the low bioavailability of this phytochemical is one of the main problems to be solved before using it as a standard therapeutic agent to treat cancer.

\section{Disclosure}

The authors report no conflicts of interest in this work.

\section{References}

1. Parker SL, Tong T, Bolden S, Wingo PA. Cancer statistics, 1997. CA Cancer J Clin. 1997;47(1):5-27.

2. Siegel RL, Miller KD, Jemal A. Cancer statistics, 2015. CA Cancer J Clin. 2015;65(1):5-29.

3. Stefan C. Will a global fund for cancer be the answer? Nat Rev Clin Oncol. 2018;15(4):195-196.

4. Desantis CE, Lin CC, Mariotto AB, et al. Cancer treatment and survivorship statistics, 2014. CA Cancer J Clin. 2014;64(4):252-271.

5. Siegel RL, Miller KD, Jemal A. Cancer statistics, 2016. CA Cancer J Clin. 2016;66(1):7-30.

6. Desantis CE. Breast Cancer Statistics, 2017, racial disparity in mortality by state. $2017 ; 67(6): 439-448$.

7. Talib WH. Consumption of garlic and lemon aqueous extracts combination reduces tumor burden by angiogenesis inhibition, apoptosis induction, and immune system modulation. Nutrition. 2017;43-44: 89-97.

8. Talib WH. Regressions of breast carcinoma syngraft following treatment with piperine in combination with thymoquinone. Sci Pharm. 2017;85(3):27-11.

9. Bordoloi D, Kunnumakkara AB. The Potential of Curcumin: A Multitargeting Agent in Cancer Cell Chemosensitization. In: Bharti AC and Aggarwal BB, editors. Role of Nutraceuticals in Chemoresistance to Cancer 2. Amsterdam: Elsevier Inc.; 2018:31-60.

10. Kim S, An SS. Role of p53 isoforms and aggregations in cancer. Medicine. 2016;95(26):e3993.

11. Parrales A, Iwakuma T. Targeting Oncogenic Mutant p53 for Cancer Therapy. Front Oncol. 2015;5(Suppl 1):288.

12. Beusterien K, Grinspan J, Kuchuk I, et al. Use of conjoint analysis to assess breast cancer patient preferences for chemotherapy side effects. Oncologist. 2014;19(2):127-134.

13. Diesendruck Y, Benhar I. Novel immune check point inhibiting antibodies in cancer therapy-Opportunities and challenges. Drug Resist Updat. 2017;30:39-47.

14. Menna P, Salvatorelli E, Minotti G. Perspective Cardiotoxicity of Antitumor Drugs. Chem Res Toxicol. 2008;21(5):978-989.

15. Escalante J, McQuade RM, Stojanovska V, Nurgali K. Impact of chemotherapy on gastrointestinal functions and the enteric nervous system. Maturitas. 2017;105:23-29.

16. Viele CS. Overview of chemotherapy-induced diarrhea. Semin Oncol Nurs. 2003;19(4 Suppl 3):2-5.
17. Kuebler JP, Wieand HS, O'Connell MJ, et al. Oxaliplatin combined with weekly bolus fluorouracil and leucovorin as surgical adjuvant chemotherapy for stage II and III colon cancer: results from NSABP C-07. J Clin Oncol. 2007;25(16):2198-2204.

18. Cao X, Nie X, Xiong S, et al. Renal protective effect of polysulfide in cisplatin-induced nephrotoxicity. Redox Biol. 2018;15:513-521.

19. Oun R, Moussa Y, Wheate N. The side effects of platinumbased chemotherapy drugs: a review for chemists. Dalton Trans. 2018;47(19):6645-6653.

20. Vinay DS, Ryan EP, Pawelec G, et al. Immune evasion in cancer: Mechanistic basis and therapeutic strategies. Semin Cancer Biol. 2015;35(Suppl):S185-S198.

21. Davis JN, Medbery C, Sharma S, et al. Stereotactic body radiotherapy for centrally located early-stage non-small cell lung cancer or lung metastases from the RSSearch ${ }^{\circledR}$ patient registry. Radiat Oncol. 2015;10(1):113.

22. Falah RR, Talib WH, Shbailat SJ. Combination of metformin and curcumin targets breast cancer in mice by angiogenesis inhibition, immune system modulation and induction of p53 independent apoptosis. Ther Adv Med Oncol. 2017;9(4):235-252.

23. Zria DAA, Osenstein BASR, Zsahin MAO. H. Radiation-induced side effects with or without systemic therapies: prime time for prediction of individual radiosensitivity. Int J Radiat Oncol Biol Phys. 2008;71(5):1293-1294.

24. Narvaez C, Doemer C, Idel C, et al. Radiotherapy related skin toxicity (RAREST-01): Mepitel $®$ film versus standard care in patients with locally advanced head-and-neck cancer. BMC Cancer. 2018;18(1):1-6.

25. Schnur JB, Ouellette SC, Dilorenzo TA, Green S, Montgomery GH. A qualitative analysis of acute skin toxicity among breast cancer radiotherapy patients. Psychooncology. 2011;20(3):260-268.

26. Schultheiss TE, Lee WR, Hunt MA, Hanlon AL, Peter RS, Hanks GE. Late GI and GU complications in the treatment of prostate cancer. Int J Radiat Oncol Biol Phys. 1997;37(1):3-11.

27. Dearnaley DP, Khoo VS, Norman AR, et al. Comparison of radiation side-effects of conformal and conventional radiotherapy in prostate cancer: a randomised trial. Lancet. 1999;353(9149):267-272.

28. Repullo D, Diaz M, Holbrechts S, et al. Unusual presentation of a hepatocellular carcinoma as a potential late side effect of radiotherapy in a patient treated for Wilms tumor in childhood. World J Surg Oncol. 2018;16(1):1-5.

29. Kovalic JJ, Thomas PRM, Beckwith JB, Feusner TJH, Norkool PA. Hepatocellular Carcinoma as Second Malignant Neoplasms in Successfully Treated Wilms' Tumor Patients. Cancer. 1991;67(2): 342-344.

30. Talib WH, Mahasneh AM. Combination of Ononis hirta and Bifidobacterium longum decreases syngeneic mouse mammary tumor burden and enhances immune response. J Cancer Res Ther. 2012;8(3):417.

31. Talib WH, Mahasneh AM. Antimicrobial, cytotoxicity and phytochemical screening of Jordanian plants used in traditional medicine. Molecules. 2010;15(3):1811-1824.

32. Farnsworth NR, Akerele O, Bingel AS, Soejarto DD, Guo Z. Medicinal plants in therapy. Bull World Health Organ . 1985;63(6):965-981.

33. Aslam MS, Ahmad MS, Mamat AS. A review on phytochemical constituents and pharmacological activities of Clinacanthus nutans. Int J Pharm Pharm Sci. 2015;7(2):30-33.

34. Khan H, Rauf A. Medicinal plants: economic perspective and recent developments. World Appl Sci J. 2014;31:1925-1929.

35. Harvey A. Strategies for discovering drugs from previously unexplored natural products. Drug Discov Today. 2000;5(7):294-300.

36. Verpoorte R. Pharmacognosy in the New Millennium: Leadfinding and Biotechnology. J Pharm Pharmacol. 2000;52:253-262.

37. Kingston DG. Modern natural products drug discovery and its relevance to biodiversity conservation. J Nat Prod. 2011;74(3):496-511.

38. Talib WH. Anticancer and antimicrobial potential of plant-derived natural products. In: Rasooli I, editor. Phytochemicals - bioactivities and impact on health. Rijeka: InTech; 2011:141-160.

39. Newman DJ, Cragg GM. Natural products as sources of new drugs over the 30 years from 1981 to 2010. JNat Prod. 2012;75(3):311-335. 
40. Eid SY, El-Readi MZ, Fatani SH, Mohamed Nour Eldin EE, Wink M. Natural products modulate the multifactorial multidrug resistance of cancer. Pharmacol Pharm. 2015;06(03):146-176.

41. Shishodia S, Sethi G, Aggarwal BB. Curcumin: getting back to the roots. Ann NY Acad Sci. 2005;1056(1):206-217.

42. Hatcher H, Planalp R, Cho J, Torti FM, Torti SV. Curcumin: from ancient medicine to current clinical trials. Cell Mol Life Sci. 2008;65(11):1631-1652.

43. Nelson KM, Dahlin JL, Bisson J, Graham J, Pauli GF, Walters MA. The essential medicinal chemistry of curcumin. J Med Chem. 2017;60(5):1620-1637.

44. Awasthi M, Singh S, Pandey VP, Dwivedi U. Curcumin: Structureactivity relationship towards its role as a versatile multi-targeted therapeutics. Mini Rev Org Chem. 2017;14(4):311-322.

45. Khalid EB, Ayman EE, Rahman H, Abdelkarim G, Najda A. Natural products against cancer angiogenesis. Tumour Biol. 2016;37(11): 14513-14536.

46. Anand P, Sundaram C, Jhurani S, Kunnumakkara AB, Aggarwal BB. Curcumin and cancer: an "old-age" disease with an "age-old" solution. Cancer Lett. 2008;267(1):133-164.

47. Ferri C, West K, Otero K, Kim YH. Effectiveness of curcumin for treating cancer during chemotherapy. Altern Complement Ther. 2018;24(1):13-18.

48. Sagar SM, Yance D, Wong RK. Natural health products that inhibit angiogenesis: a potential source for investigational new agents to treat cancer-Part 1. Curr Oncol. 2006;13(1):14-26.

49. Bahmani M, Shirzad H, Shahinfard N, Sheivandi L, Rafieian-Kopaei M. Cancer Phytotherapy: Recent Views on the Role of Antioxidant and Angiogenesis Activities. J Evid Based Complement Altern Med 2017;22(2):299-309.

50. Bi YH, Zhang LH, Chen SJ, Ling QZ, Chen S. Antitumor mechanisms of curcumae rhizoma based on network pharmacology. Evid Based Complement Alternat Med. 2018;2018:1-9.

51. Yang J, Wang C, Zhang Z, et al. Curcumin inhibits the survival and metastasis of prostate cancer cells via the Notch-1 signaling pathway. APMIS. 2017;125(2):134-140.

52. Li Y, Domina A, Lim G, Chang T, Zhang T. Evaluation of curcumin, a natural product in turmeric, on Burkitt lymphoma and acute myeloid leukemia cancer stem cell markers. Future Oncol. 2018;14(23):2353-2360.

53. Su P, Yang Y, Wang G, Chen X, Ju Y. Curcumin attenuates resistance to irinotecan via induction of apoptosis of cancer stem cells in chemoresistant colon cancer cells. Int J Oncol. 2018;53(3):1343-1353.

54. Li X, Wang X, Xie C, et al. Sonic hedgehog and Wnt/ $\beta$-catenin pathways mediate curcumin inhibition of breast cancer stem cells. Anticancer Drugs. 2018;29(3):208-215.

55. Sun M, Su X, Ding B, et al. Advances in nanotechnology-based delivery systems for curcumin. Nanomedicine. 2012;7(7):1085-1100.

56. Atanasov AG, Waltenberger B, Pferschy-Wenzig EM, et al. Discovery and resupply of pharmacologically active plant-derived natural products: a review. Biotechnol Adv. 2015;33(8):1582-1614.

57. Bansal SS, Goel M, Aqil F, Vadhanam MV, Gupta RC. Advanced drug delivery systems of curcumin for cancer chemoprevention. Cancer Prev Res. 2011;4(8):1158-1171.

58. Tabatabaei Mirakabad FS, Akbarzadeh A, Milani M, et al. A Comparison between the cytotoxic effects of pure curcumin and curcuminloaded PLGA-PEG nanoparticles on the MCF-7 human breast cancer cell line. Artif Cells Nanomed Biotechnol. 2016;44(1):423-430.

59. Joerger AC, Fersht AR. Structural biology of the tumor suppressor p53. Annu Rev Biochem. 2008;77(1):557-582.

60. Weinberg Robert A. The biology of cancer. J Chem Inf Model. 2013;53:1689-1699.

61. Talib WH, Al Kury LT. Parthenolide inhibits tumor-promoting effects of nicotine in lung cancer by inducing P53-dependent apoptosis and inhibiting VEGF expression. Biomed Pharmacother. 2018;107:1488-1495.

62. Mills KD. Tumor suppression: putting p53 in context. Cell Cycle. 2013;12(22):3461-3462.
63. Vousden KH, Lu X. Live or let die: the cell's response to p53. Nat Rev Cancer. 2002;2(8):594-604.

64. Slee EA, O'Connor DJ, Lu X. To die or not to die: how does p53 decide? Oncogene. 2004;23(16):2809-2818.

65. Ventura A, Kirsch DG, McLaughlin ME, et al. Restoration of p53 function leads to tumour regression in vivo. Nature. 2007;445(7128):661-665.

66. Mitkin NA, Hook CD, Schwartz AM, et al. p53-dependent expression of CXCR5 chemokine receptor in MCF-7 breast cancer cells. Sci Rep. 2015;5:9330

67. Meek DW. Mechanisms of switching on p53: a role for covalent modification? Oncogene. 1999;18(53):7666-7675.

68. Momand J, Wu HH, Dasgupta G. MDM2 - master regulator of the p53 tumor suppressor protein. Gene. 2000;242(1-2):15-29.

69. Wu X, Bayle JH, Olson D, Levine AJ. The p53-mdm-2 autoregulatory feedback loop. Genes Dev. 1993;53:1126-1132.

70. Tokino T, Nakamura Y. The role of p53-target genes in human cancer. Crit Rev Oncol Hematol. 2000;33(1):1-6.

71. Ryan KM, Phillips AC, Vousden KH. Regulation and function of the p53 tumor suppressor protein. Curr Opin Cell Biol. 2001;13(3):332-337.

72. Labuschagne CF, Zani F, Vousden KH. Control of metabolism by p53 - Cancer and beyond. Biochim Biophys Acta Rev Cancer. 2018;1870(1):32-42.

73. Haupt S, Berger M, Goldberg Z, Haupt Y. Apoptosis - the p53 network J Cell Sci. 2003;116(Pt 20):4077-4085.

74. Schuler M, Green DR. Mechanisms of p53-dependent apoptosis. Biochem Soc Trans. 2001;29(Pt 6):684-688.

75. Oren M. Decision making by p53: life, death and cancer. Cell Death Differ. 2003;10(4):431-442.

76. Hong B, van den Heuvel AP, Prabhu VV, Zhang S, El-Deiry WS. Targeting tumor suppressor p53 for cancer therapy: strategies, challenges and opportunities. Curr Drug Targets. 2014;15(1):80-89.

77. Goh AM, Coffill CR, Lane DP. The role of mutant p53 in human cancer J Pathol. 2011;223(2):116-126.

78. Stegh AH. Targeting the p53 signaling pathway in cancer therapy - the promises, challenges and perils. Expert Opin Ther Targets. 2012;16(1):67-83.

79. Robles AI, Harris CC. Clinical outcomes and correlates of TP53 mutations and cancer. Cold Spring Harb. Perspect. Biol. 2009;2(3):a001016.

80. Levine AJ. p53, the cellular gatekeeper for growth and division. Cell. 1997;88(3):323-331.

81. Bianconi E, Piovesan A, Facchin F, et al. An estimation of the number of cells in the human body. Ann Hum Biol. 2013;40(6):463-471.

82. Veeraraghavan J, Natarajan M, Herman TS, Aravindan N. Curcuminaltered p53-Response Genes Regulate Radiosensitivity in p53 -Mutant Ewings Sarcoma Cells. Anticancer Res. 2010;4016:4007-4015.

83. Song G, Mao YB, Cai QF, Yao LM, Ouyang GL, Bao SD. Curcumin induces human HT-29 colon adenocarcinoma cell apoptosis by activating p53 and regulating apoptosis-related protein expression. Braz J Med Biol Res. 2005;38(12):1791-1798.

84. Xu S, Yang Z, Fan Y, et al. Curcumin enhances temsirolimus-induced apoptosis in human renal carcinoma cells through upregulation of YAP/p53. Oncol Lett. 2016;12(6):4999-5006.

85. Wang Y, Yu J, Cui R, Lin J, Ding X. Curcumin in treating breast cancer: a review. J Lab Autom. 2016;21(6):723-731.

86. Choudhuri T, Pal S, Agwarwal ML, Das T, Sa G. Curcumin induces apoptosis in human breast cancer cells through p53-dependent Bax induction. FEBS Lett. 2002;512(1-3):334-340.

87. Fu H, Wang C, Yang D, et al. Curcumin regulates proliferation, autophagy, and apoptosis in gastric cancer cells by affecting PI3K and P53 signaling. J Cell Physiol. 2018;233(6):4634-4642.

88. Ramachandran C. Expression profiles of apoptotic genes induced by curcumin in human breast cancer and mammary epithelial cell lines. Anticancer Res. 2005;25(5):3293-3302.

89. Quan J, Li Y, Jin M, Chen D, Yin X, Jin M. Suppression of p53-inducible gene 3 is significant for glioblastoma progression and predicts poor patient prognosis. Tumour Biol. 2017;39(3):101042831769457. 
90. Kato S, Han S-Y, Liu W, et al. Understanding the function-structure and function-mutation relationships of p53 tumor suppressor protein by high-resolution missense mutation analysis. Proc Natl Acad Sci US A. 2003;100(14):8424-8429.

91. Rafiq S, Raza MH, Younas M, et al. Molecular targets of curcumin and future therapeutic role in leukemia. J Biosci Med. 2018;06(04): 33-50.

92. Aggarwal S. Curcumin (Diferuloylmethane) Down-Regulates Expression of Cell Proliferation and Antiapoptotic and Metastatic Gene Products through Suppression of IkappaBalpha kinase and Akt Activation. Mol Pharmacol. 2006;69:195-206.

93. Chiu T, Su C. Curcumin inhibits proliferation and migration by increasing the Bax to Bcl-2 ratio and decreasing NF- $\kappa \mathrm{B}$ p65 expression in breast cancer MDA-MB-231 cells. Int J Mol Med. 2009:469-475.

94. Ramachandran C, You W. Differential sensitivity of human mammary epithelial and breast carcinoma cell lines to curcumin. Breast Cancer Res Treat. 1999;54(3):269-278.

95. Aggarwal BB, Kumar A, Bharti AC. Anticancer potential of curcumin: preclinical and clinical studies. Anticancer Res. 2003;23(1A):363-398.

96. Reuter S, Eifes S, Dicato M, Aggarwal BB, Diederich M. Modulation of anti-apoptotic and survival pathways by curcumin as a strategy to induce apoptosis in cancer cells. Biochem Pharmacol. 2008;76(11):1340-1351.

97. Woo J. Molecular mechanisms of curcumin-induced cytotoxicity: induction of apoptosis through generation of reactive oxygen species, down-regulation of Bcl-X L and IAP, the release of cytochrome $\mathrm{c}$ and inhibition of Akt. Carcinogenesis. 2003;24:1199-1208.

98. Shehzad A, Lee J, Huh TL, Lee YS. Curcumin induces apoptosis in human colorectal carcinoma (HCT-15) cells by regulating expression of Prp4 and p53. Mol Cells. 2013;35(6):526-532.

99. Choudhuri T, Pal S, Das T, Sa G. Curcumin Selectively Induces Apoptosis in Deregulated Cyclin D1-expressed Cells at G 2 Phase of Cell Cycle in a p53-dependent Manner. J Biol Chem. 2005;280: 20059-20068.

100. Liu E, Wu J, Cao W, et al. Curcumin induces G2/M cell cycle arrest in a p53-dependent manner and upregulates ING4 expression in human glioma. J Neurooncol. 2007;85(3):263-270.

101. Lopiccolo J, Blumenthal GM, Bernstein WB, Dennis PA. Targeting the PI3K/Akt/mTOR pathway: effective combinations and clinical considerations. Drug Resist Updat. 2008;11(1-2):32-50.

102. Jin H, Lian N, Zhang F, et al. Activation of PPAR $\gamma / \mathrm{P} 53$ signaling is required for curcumin to induce hepatic stellate cell senescence. Cell Death Dis. 2016;7(4):e2189.

103. das L, Vinayak M. Long term effect of curcumin in restoration of tumour suppressor p53 and phase-II antioxidant enzymes via activation of Nrf2 signalling and modulation of inflammation in prevention of cancer. PLoS One. 2015;10(4):e0124000-e0124023.

104. Collins HM, Abdelghany MK, Messmer M, et al. Differential effects of garcinol and curcumin on histone and p53 modifications in tumour cells. BMC Cancer. 2013;13(1):37.

105. Li W, Wang Y, Song Y, Xu L, Zhao J, Fang B. A preliminary study of the effect of curcumin on the expression of $\mathrm{p} 53$ protein in a human multiple myeloma cell line. Oncol Lett. 2015;9(4):1719-1724.

106. Zhou B, Zuo Y, Li B, et al. Deubiquitinase inhibition of $19 \mathrm{~S}$ regulatory particles by 4-arylidene curcumin analog AC17 causes NF- $\kappa \mathrm{B}$ inhibition and 553 reactivation in human lung cancer cells. Mol Cancer Ther. 2013;12(8):1381-1392.

107. Madan E, Parker TM, Bauer MR, et al. The curcumin analog HO-3867 selectively kills cancer cells by converting mutant p53 protein to transcriptionally active wildtype p53. J Biol Chem. 2018;293(12):4262-4276.

108. Wang J, Xie H, Gao F, Zhao T, Yang H, Kang B. Curcumin induces apoptosis in p53-null Hep3B cells through a TAp73/DNp73-dependent pathway. Tumour Biol. 2016;37(3):4203-4212.

109. Watson JL, Hill R, Yaffe PB, et al. Curcumin causes superoxide anion production and p53-independent apoptosis in human colon cancer cells. Cancer Lett. 2010;297(1):1-8.
110. Beevers CS, Li F, Liu L, Huang S. Curcumin inhibits the mammalian target of rapamycin-mediated signaling pathways in cancer cells. Int J Cancer. 2006;119(4):757-764.

111. Astuti P, Utami D, Nugrahani E, Sudjadi S. Genistein abrogates G2 arrest induced by curcumin in p53 deficient T47D cells. Daru. 2012;20(1):1-8.

112. Li F, Chen $\mathrm{X}, \mathrm{Xu} \mathrm{B}$, Zhou H. Curcumin induces p53-independent necrosis in $\mathrm{H} 1299$ cells via a mitochondria-associated pathway. Mol Med Rep. 2015;12(5):7806-7814.

113. He ZY, Shi CB, Wen H, Li FL, Wang BL, Wang J. Upregulation of p53 expression in patients with colorectal cancer by administration of curcumin. Cancer Invest. 2011;29(3):208-213.

114. Tsvetkov P, Asher G, Reiss V, Shaul Y, Sachs L, Lotem J. Inhibition of NAD(P)H:quinone oxidoreductase 1 activity and induction of p53 degradation by the natural phenolic compound curcumin. Proc Natl Acad Sci USA. 2005;102(15):5535-5540.

115. Liontas A, Yeger H. Curcumin and resveratrol induce apoptosis and nuclear translocation and activation of p53 in human neuroblastoma. Anticancer Res. 2004;24(2B):987-998.

116. Pan W, Yang H, Cao C, et al. AMPK mediates curcumin-induced cell death in CaOV3 ovarian cancer cells. Oncol Rep. 2008;20(6):1553-1559.

117. Thayyullathil F, Chathoth S, Hago A, Patel M, Galadari S. Rapid reactive oxygen species (ROS) generation induced by curcumin leads to caspase-dependent and -independent apoptosis in L929 cells. Free Radic Biol Med. 2008;45(10):1403-1412.

118. Watson JL, Greenshields A, Hill R, et al. Curcumin-induced apoptosis in ovarian carcinoma cells is p53-independent and involves p38 mitogenactivated protein kinase activation and downregulation of Bcl-2 and survivin expression and Akt signaling. Mol Carcinog. 2010;49(1):13-24.

119. Sa G, Das T. Anti cancer effects of curcumin: cycle of life and death. Cell Div. 2008;3(1):14-14.

120. Balasubramanyam K, Varier RA, Altaf M, et al. Curcumin, a novel p300/CREB-binding protein-specific inhibitor of acetyltransferase, represses the acetylation of histone/nonhistone proteins and histone acetyltransferase-dependent chromatin transcription. J Biol Chem. 2004;279(49):51163-51171.

121. Liu Q, Loo WT, Sze SC, Tong Y. Curcumin inhibits cell proliferation of MDA-MB-231 and BT-483 breast cancer cells mediated by down-regulation of NFkappaB, cyclinD and MMP-1 transcription. Phytomedicine. 2009;16(10):916-922.

122. Hallman $\mathrm{K}$. The effects of turmeric (curcumin) on tumor suppressor protein (p53) and estrogen receptor (ER $\alpha)$ in breast cancer cells. Breast Cancer (Dove Med Press). 2017;9:153-161.

123. Sen GS. Curcumin Enhances the Efficacy of Chemotherapy by Tailoring p65NF $\square$ B-p300 Cross-talk in Favor of p53-p300 in Breast Cancer. J Biol Chem. 2011;286:42232-42247.

124. Zhou QM, Wang XF, Liu XJ, Zhang H, Lu YY, Su SB. Curcumin enhanced antiproliferative effect of mitomycin $\mathrm{C}$ in human breast cancer MCF-7 cells in vitro and in vivo. Acta Pharmacol Sin. 2011;32(11): $1402-1410$.

125. Altenburg JD, Bieberich AA, Terry C, et al. A synergistic antiproliferation effect of curcumin and docosahexaenoic acid in SK-BR-3 breast cancer cells: unique signaling not explained by the effects of either compound alone. BMC Cancer. 2011;11(1):1-16.

126. Li X. Curcumin Modulates miR-19/PTEN/AKT/p53 Axis to Suppress Bisphenol A-induced MCF-7 Breast Cancer Cell Proliferation. 2014;28(10):1553-1560.

127. Patel PB, Thakkar VR, Patel JS. Cellular effect of curcumin and citral combination on breast cancer cells: induction of apoptosis and cell cycle arrest. J Breast Cancer. 2015;18(3):225.

128. Bimonte S, Barbieri A, Palma G. Dissecting the role of curcumin in tumour growth and angiogenesis in mouse model of human breast cancer. Biomed Res Int. 2015;2015:878134.

129. Aggarwal BB, Shishodia S, Takada Y, et al. Curcumin suppresses the paclitaxel-induced nuclear factor-kappaB pathway in breast cancer cells and inhibits lung metastasis of human breast cancer in nude mice. Clin Cancer Res. 2005;11(20):7490-7498. 
130. Lv ZD, Liu XP, Zhao WJ, et al. Curcumin induces apoptosis in breast cancer cells and inhibits tumor growth in vitro and in vivo. Int J Clin Exp Pathol. 2014;7(6):2818-2824.

131. Faião-flores F, Maria DA. DM-1, sodium 4-[5-(4-hydroxy-3methoxyphenyl)-3-oxo- penta-1,4-dienyl]-2-methoxy-phenolate: a curcumin analog with a synergic effect in combination with paclitaxel in breast cancer treatment. Tumour Biol. 2012;33(3):775-785.
132. Somasundaram S. Dietary curcumin inhibits chemotherapy-induced apoptosis in models of human breast cancer dietary curcumin inhibits chemotherapy-induced apoptosis in models of human. Cancer Res. 2002;62(13):3868-3875.

133. Pal K, Laha D, Parida PK, et al. An in vivo study for targeted delivery of curcumin in human triple negative breast carcinoma cells conjugated with folic acid. J Nanosci Nanotechnol. 2018;18:1-14.
Breast Cancer - Targets and Therapy

\section{Publish your work in this journal}

Breast Cancer - Targets and Therapy is an international, peerreviewed open access journal focusing on breast cancer research, identification of therapeutic targets and the optimal use of preventative and integrated treatment interventions to achieve improved outcomes, enhanced survival and quality of life for the cancer patient

\section{Dovepress}

The manuscript management system is completely online and includes a very quick and fair peer-review system, which is all easy to use. Visit http://www.dovepress.com/testimonials.php to read real quotes from published authors. 